\title{
Community Participation and Sustainability Issue: An Evaluation of a Donor-Driven Water Sector in Ikaram Millennium Village Project, Nigeria
}

\author{
Ayo Emmanuel Olajuyigbe \\ Department of Urban and Regional Planning, Federal University of Technology, Akure, Nigeria \\ Email: olajuyigbe03@yahoo.com
}

Received 3 May 2016; accepted 12 June 2016; published 15 June 2016

Copyright (C 2016 by author and Scientific Research Publishing Inc.

This work is licensed under the Creative Commons Attribution International License (CC BY). http://creativecommons.org/licenses/by/4.0/

(c) (i) Open Access

\section{Abstract}

This study examines the extent to which community participation influences community ownership of water project and its sustainability in Ikaram Millennium Village (MV). Structured closeended questionnaire and semi-structure open-ended interview checklist were used to elicit information from respondents including households, key informants, MV officials, Water and Sanitation (WASH) Committee members and staff of Ondo State Multilateral Agency that oversaw the project. From the projected population of 22,863 , the household size in the cluster was estimated to be 3266 households using national average family size of 7 . Thereafter, $5 \%$ of the total number of households in Ikaram MV was chosen, amounting to 163. The household survey was administered using simple random sampling technique. Key Informant Interviews (KII) and Focus Group Discussions (FGDs) were also conducted. The study established that due to low economic base of the MV, low financial and local materials were contributed towards the water project development. It was found that $84.2 \%$ of the population in the MV was willing to contribute less than $\$ 1000$ for the maintenance of the various water facilities. It was further observed during the FGD, that the different types of existing community institutions were not fully consulted. The findings estabilished that two persons in each community were trained to handle construction of water and sanitary facilities while the other two received training on the repair and maintenance of these facilities. The result also indicated that repair works were usually handled by the Water Committee while fund for the payment of the repair services was obtained from the pool of money contributed by the community members. By implication, financial incapability of the community members will to a large extent affect the maintenance of the water source points and by extension inhibits the sustainability of the water and sanitation projects.

\section{Keywords}

Community Participation, Water and Sanitation Facilities, Sustainability, Household Survey, 


\section{Community Ownership}

\section{Introduction}

Low levels of access to clean water by a large proportion of humanity have been reported [1]-[4]. Africa is the region that suffers most from inadequate access to water supply [3]-[7]. In Nigeria, a large proportion of both urban and rural population do not have have access to safe drinking water [3] [4] [7]. Improved access to safe drinking water is a prerequisite to poverty reduction. Access to safe drinking water prevents the spread of waterborne and sanitation-related diseases. In view of the importance of water to humanity, donors have demonstrated keen interest in enhancing this sector over the years.

In 2002, the then UN-secretary general Koffi Annan perceived that it will be very difficult to achieve the MDGs in sub-Saharan Africa countries by 2015. He then set up a committee which was headed by Jeffrey Sachs, the Secretary-General's Special Advisor on the MDGs. The outcome of the report tendered by the committee gave birth to the Millennium Village Project (MVP) initiative. The project was to address developmental issues in Africa countries; bring out projects which are replicable, scalable and sustainable to the poorest poor of the rural inhabitants of sub-Saharan Africa. MVP was designed as a practical proof of concept to demonstrate MDGs in time-bound fashion in African rural areas. Millennium village initiative aims to spark local economic development in fourteen village clusters across Africa and show that people in the poorest regions of rural Africa can lift themselves out of extreme poverty after fifth year of intervention [8]. Specifically, MVP is a partnership initiative designed to identify and scale-up solutions to the challenge of integrated rural development [9].

In Nigeria, MVP is located in two selected clusters. These are Pampaida in Kaduna State and Ikaramin Ondo State. The locations are influenced by some factors; areas falling within hunger spot, areas which are peaceful and are thirsty to meet the MDGs, areas with good management structure between the communities, state and national government and areas located in an agro-ecological zones. The Ikaram MVP was supported by the Earth Institute, Columbia University, Millennium promise, UNDP, Japanese government and Ondo State government. One of the goals of the Ikaram MVP was to enhance access to basic sanitation and domestic water supply. Its specific targets in the area of sanitation include: firstly, accessibility of all members of households to an improved sanitation facilities that is shared by no more than 20 people within $25 \mathrm{~m}$. Secondly, provision of separate sanitation facilities for girls and boys in schools. Thirdly, increase use of sanitation facilities leading to decrease incidence of water borne diseases.

In view of the importance of water to human health, MVP was designed to provide rigorous proof of concept for integrated community based on low cost intervention and identify means of scaling up those interventions that will achieve MDGs. High level of community participation was seen as a key strategy to achieving this target. It is however realised that community participation in water programmes is usually being limited to mobilisation of self-help labour or the organisation of local groups to ratify decisions made by project planners outside the community [10]. This narrow conception has very serious inherent limitations to successful implementation of rural water programmes. Thus, the emphasis is again shifted to community management. Present drinking water policies assume that the facilities can and should be best managed by local user communities. It is expected that communal management will guarantee the technical sustainability of the facilities as well as give more equal access to water [11]. It should be noted that every person possesses a subconscious concern to maintain, preserve and defend the access to the water which they need for their own survival. Water supply management is pivotal to ensure sufficient amount of good quality water for the community. As a result, water management has emerged as an essential part of the organizational structure of community life. This management starts from the simplest family groups and has gradually become complex and more important in response to the situation caused by water scarcity or increasing population density. Management for water supply has been defined as the marshalling of resources to plan, direct, monitor and evaluate the operation and maintenance (O\&M) of water supply [12].

After a careful scrutiny of a research [13] carried out on how best to achieve millenium goals on water and sanitation in Ikaram, it was observed that the research fails to consider the role of community ownership and management in Ikaram Millennium Village. In a research work on "Does user participation lead to sense of ownership in rural water supply systems with evidence from Kenya, it has been observed that the research is li- 
mited to developing measuring tools for household sense of ownership for their water systems but failed to identify the relationship between sense of ownership and sustainability of water projects [14]. In a recent research [15] on rural water supply systems in the Niger Delta region of Nigeria, there was an explicit emphasis on sustainability of water supply with little or no attention on community ownership and management of water supply. Research has shown that for improved and life long capacity of water supply systems, there must be genuine participation rather than glorified tokenism. This study therefore attempts to examine and explain extent to which community participation influences community owner ship of water projects and community ownership as an influencing factor of sustainability of water projects in Ikaram millennium Village. This research work seeks to address this gap since it is evident that without proper structures in place for community ownership and management of water, the sustainability of water projects may be unrealizable.

\section{Conceptual Framework}

\subsection{Community Management Model}

The conceptual model for this study is the Community Management Model (CMM) of rural water provision. The model was developed over the last two decades when it was recognized that despite the improvement in the rural water provision through supply driven strategy, provision of adequate water for teeming rural dwellers was not achieved. Therefore, the model has been seen as an answer to the failure of previous supply driven approaches to providing services, which often did not meet the real needs of users and resulted in systems which often break down earlier than the end of the design life [16].

Community Management Model is a conceptual framework within which the improvement in rural water supply is achieved by involving community concerned in the whole process. This model enables people to take control of the operation and administration of their own Rural Water Supply (RWS) System completely and indefinitely.

The model takes into account the participation of the community members; control over decision making, ownership and cost sharing. The model is viewed as central to long-term operation and maintenance. The main concerns of this model are empowerment, efficiency and sustainability.

CMM of rural water supply is based on the following principles [16]:

a) Participation: A cross-section of the community must be involved and participate actively in water development process.

b) Control: The community must be in charge of the operation and management of its own water supply system. The control means ability of the community to make strategic decisions about the process, from the design phase to long term operation and management (O\&M).

c) Ownership: The community must own the water infrastructure. This may not always be possible in existing legal frameworks. However, there must be perception of ownership by the user community.

d) Cost sharing: There must be element of community contribution to the recurrent costs of running and maintaining the system. Such contribution might not necessarily be financial in nature.

\subsection{Concept of Sustainability}

In the context of this report, sustainability is best defined pragmatically as "whether or not something continues to work overtime" [17]. More specifically for this research, it implies the ability to recover from technical breakdown in the scheme. Built into common conceptions of the term are notions of minimal external support, village-level financing and the continuation of a beneficial service over time [18]. It is estimated that 35\% of all rural water supplies in sub-Saharan Africa are not functioning [19], and despite the frequency with which it appears in development discourse, the reality of sustainability remains elusive. Sustainability pertains to multiple aspects of a rural water supply, with institutional, social, technical, environmental and financial dimensions [20]. This accounts for the fact that understanding and measuring sustainability is so difficult, and why solutions are highly context specific. Studies have been conducted on water project sustainability which includes: a study that observed that most water projects did not function to full capacity and recommended for more study to be done on the influence of project location on sustainability of water projects [21]; a study that observed that most water projects decline in performance shortly after external support is withdrawn and recommended that further study be done on factors that influence sustainability of such projects in other rural parts of other countries in Africa in 
order to bring a generalization of the findings [22]. Others point out that lack of project sustainability is due to low level of community awareness, approaches used by developers and lack of proper feasibility study [23] and [24]. This study addresses the influence that community participation, control, ownership and cost sharing have on the sustainability of water projects in Ikaram Millennium Village (MV), Ondo state, Nigeria.

\section{Research Methodology}

\subsection{The Study Area}

Ikaram MV is located in Akoko North East Local Government Area (LGA), Ondo State, South West Nigeria. Ikaram MV is a group of villages comprising of 7 communities namely Ikaram, Ibaram, Iyani, Ase, Erusu, Gedegede and Ajowa (Figure 1 \& Figure 2). These villages are contiguously located to each other. The Ikaram MV was established in May 2006. The MV has an estimated population of 22,863 people. Prior the intervention, most households in the study area depended on unimproved sources of water for their domestic need.

\subsection{The Database}

Structured close-ended questionnaire and semi-structure open-ended interview checklist were used to elicit information on the socio-economic characteristics of the respondents. The major groups of respondents identified as the sample frame are the households in the MV, key informants, MV officials, Water and Sanitation (WASH)

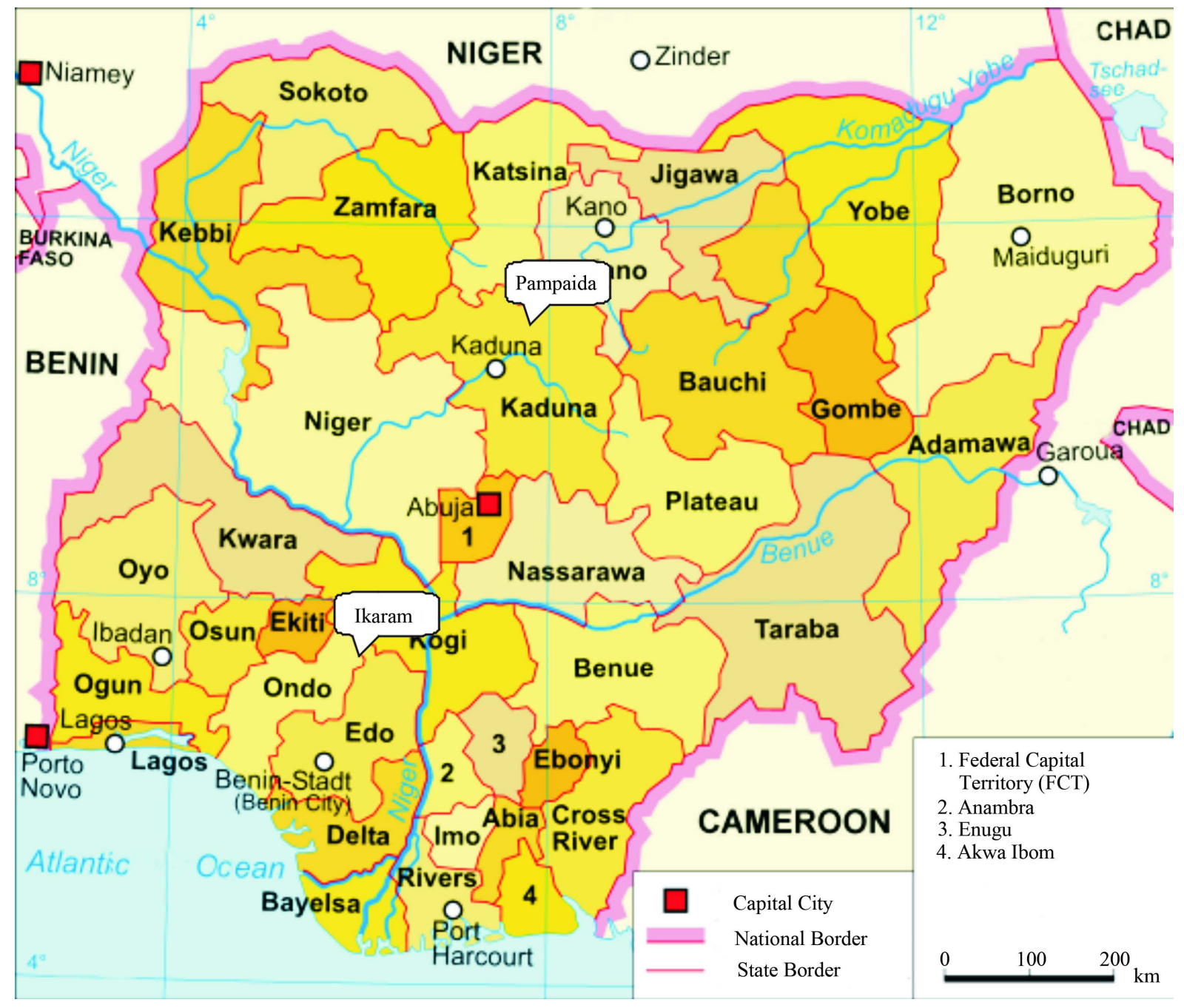

Figure 1. Ikaram and Pampaida millennium village in Nigeria (Source: Chovwen et al., 2009). 


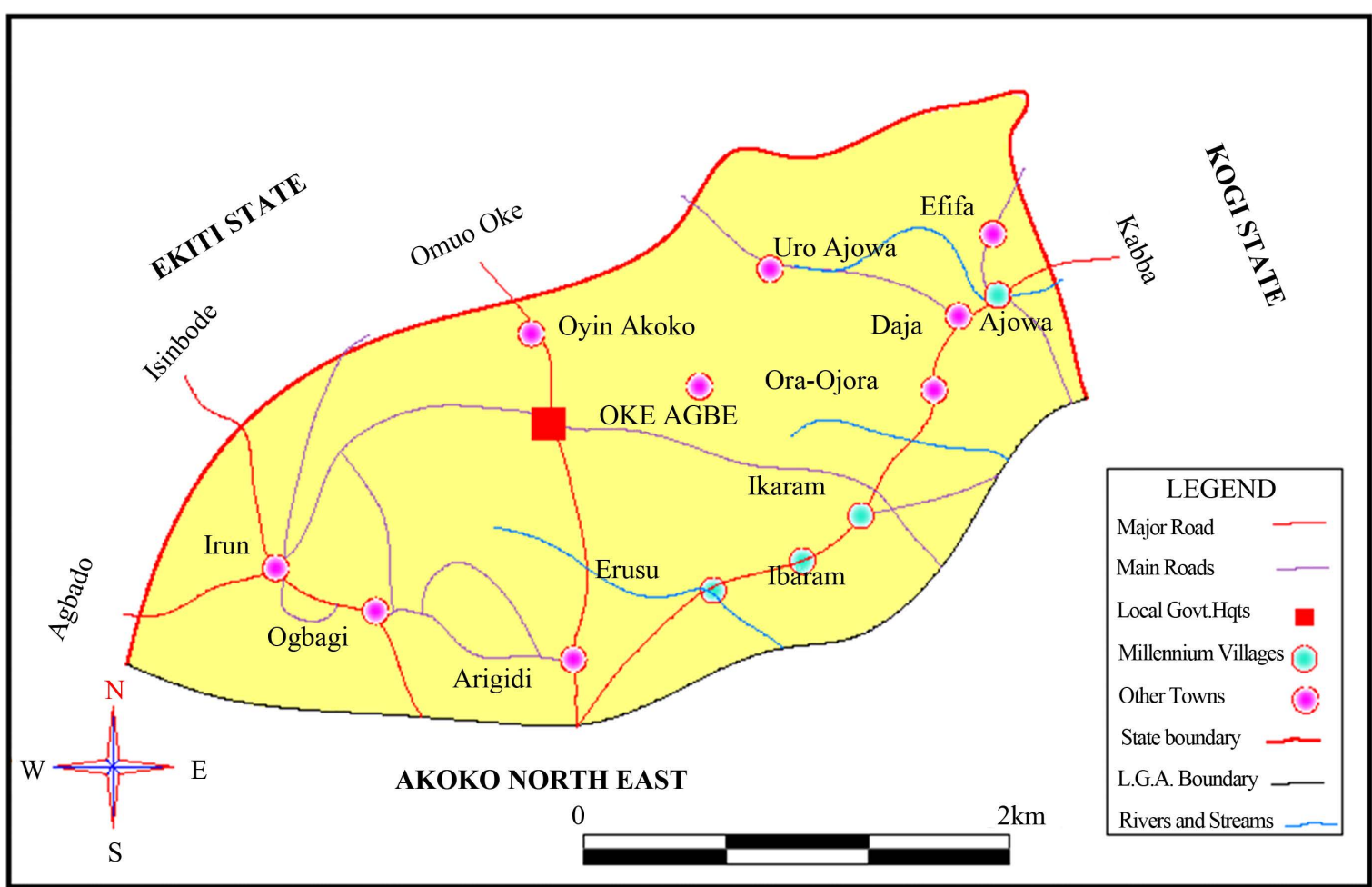

Figure 2. Akoko north west in the context of Ondo State (Source: Ondo State ministry of housing and Urban development, 2015).

Committee and Ondo State Multilateral Agency that oversaw the project. The household questionnaire was divided into four (4) sections namely demographic and socio-cultural characteristics, economic characteristics, water and sanitation issues and community participation issues. At the onset of the millennium initiative in 2006, the cluster has an estimated population of 18,307 [13]. Using a 2.5\% growth rate, the current population of the study area was estimated at 22,863. An average family size in Nigeria has been estimated to be 7 [25]. This implies that there were about 3266 households in Ikaram cluster. A sample size of 163, amounting to $5 \%$ of the total number of households in Ikaram MV was chosen (Table 1). This is considered as plausible since there are traits of homogeneity in habitability pattern in the study area.

Structured close-ended questionnaire were deployed for the household survey while simple random sampling technique was employed to administer these questionnaire. In all, 163 copies of questionnaire were randomly administered and retrieved. In addition, Key Informant Interviews (KII) were held with some individuals in the communities who have deep (local) knowledge of the areas and who could give an objective view from their experience and expertise. Such personnel include youth leaders, women leaders, Chairmen of Community Development Associations, resident teachers, health officials and community leaders. In addition, Focus Group Discussions (FGDs) were held with carefully selected group of people with adequate knowledge in the specific area of discussion. The areas include; demographic issues, infrastructures, social services, economic issues, environmental issues, water and sanitation and development activities among others. Both KII and FGD were designed to clarify and validate responses in the administered questionnaire and issues discussed by a larger group. These two methods ensured that target segments of the communities (youths, women and opinion leaders) were involved in data gathering.

\subsection{Data Analysis Technique}

The returned questionnaires were checked for errors before coding and analysis. Subsequently, these data was processed and analysed using descriptive statistics and presented through percentages, means, standard deviations and frequencies. Information obtained from KII and FGD were used to augment and validate results obtained from the quantitative data that were acquired from the household survey. 
Table 1. Sampled population for the study.

\begin{tabular}{ccccc}
\hline Community & * Base Population (2006) & Estimated Population (2015) & Estimated Housing Units & Sample Size \\
\hline Erusu & 3067 & 3830 & 547 & 27 \\
Ibaram & 613 & 766 & 109 & 5 \\
Iyani & 514 & 642 & 92 & 5 \\
Ikaram & 4982 & 6622 & 888 & 44 \\
Ase & 72 & 90 & 13 & 1 \\
Gedegede & 995 & 1243 & 178 & 9 \\
Ajowa & 8064 & 10,070 & 1439 & 72 \\
Total & $\mathbf{1 8 , 3 0 7}$ & $\mathbf{2 2 , 8 6 3}$ & $\mathbf{3 2 6 6}$ & $\mathbf{1 6 3}$ \\
\hline
\end{tabular}

Source: Author's fieldwork, 2015; "Base population is adapted from Anthony Chovwen et al. (2009).

\section{Results and Discussion}

\subsection{Socio-Economic Traits}

In the MV, $72.4 \%$ of the household heads were males and $27.6 \%$ were females (Table 2). The predominance of male household headsin the MVis a typical reflection of any Yoruba setting where males usually constitute the majority of household heads [26]. Average household size in the MV was 8, which is higher than the estimated 7 persons per household as reported by [25]. It was also observed that $56.6 \%$ of the respondents villagers were within the age group of 18 - 40 (Table 2). This indicates that the area is dominated by productive age group.

Educational level of respondents in the cluster was high as $83.9 \%$ attained secondary and post secondary levels of education while only 3.1\% interviewed did not have formal education (Table 2). The implication of this high level of education among the people could go a long way to influence sustainability of this project because it could be deduced that the educated members of the community will be expected to appreciate the need for quality water.

Most residents were self employed as they were largely engaged in trading (30.6\%) and farming (16.3\%). However, 25.5\% engaged in civil service (Table 2). In general, there was a low level of unemployment as most residents were self-employed. This situation may positively affect sustainability as they could muster resources to maintain the donor-supported water facilities and even scale up these facilities.

Findings revealed that $79.7 \%$ of the respondents earned below N200,000 per annum. It should be noted that the national minimum wage in Nigeria is N216,000 per annum. This low level of income is a reflection of the types of occupation in the study area. Low income distribution tends to inhibit propensity to sustain and scale up water facilities in the study area.

The baseline study revealed that the 4 health centres and 13 out of the 16 primary schools in the project area did not have safe drinking water points before the project's intervention. Also, only 5.6\% of the population had access to safe water. Accross the villages, there were 738 hand dug wells out of which 313 were perennial. Thus, 425 hand-dug wells usually dried up during the dry season. It was reported that out of 34 hand pumps fitted to boreholes, only 21 were functional. In like manner, out of 28 motorised boreholes in these communities, only 16 were functional [27]. Essentially, the main sources of water for the population of 18,003 during the wet season were rainwater collection (36.28\%), household wells (33.63\%) and communal wells (20.80\%). During the dry season, households relied on household wells and communal wells as the major source of water for domestic use [27].

Table 3 indicates that 40 water points were provided by the donors in Ikaram MV. Considering the population, number of existing and functional water points; there is the need for maximum attention in terms of maintaining and replicating such water points in order to meet the water need of the teeming population.

\subsection{Participation}

To ensure sustainability, a cross-section of the community must be involved and participate actively in water development process. However, investigation revealed that the MVP concentrated more on the village elders in 
Table 2. Socio-economic traits of respondents.

\begin{tabular}{|c|c|}
\hline Variable & Percent \\
\hline $\begin{array}{c}\text { Gender } \\
\text { Male } \\
\text { Female }\end{array}$ & $\begin{array}{l}72.4 \\
27.6\end{array}$ \\
\hline $\begin{array}{c}\text { Age } \\
18-30 \text { yrs } \\
31-40 \text { yrs } \\
41-55 \text { yrs } \\
\text { Below } 55 \text { yrs }\end{array}$ & $\begin{array}{l}30.3 \\
26.3 \\
18.2 \\
25.3\end{array}$ \\
\hline $\begin{array}{c}\text { Education } \\
\text { None } \\
\text { Primary } \\
\text { Secondary } \\
\text { Post secondary }\end{array}$ & $\begin{array}{c}3.0 \\
13.1 \\
35.4 \\
48.5\end{array}$ \\
\hline $\begin{array}{c}\text { Employment Status } \\
\text { Trading } \\
\text { Farming } \\
\text { Civil Service } \\
\text { Artisan } \\
\text { Others }\end{array}$ & $\begin{array}{l}30.6 \\
16.3 \\
25.5 \\
10.2 \\
17.4\end{array}$ \\
\hline $\begin{array}{c}\text { Average AnnualIncom } \\
\leq \# 50,000 \\
\# 50,001-100,000 \\
\# 100,001-150,000 \\
\# 150,001-200,000 \\
\# 200,001-250,000\end{array}$ & $\begin{array}{c}34.3 \\
28.3 \\
13.1 \\
4.0 \\
1.0\end{array}$ \\
\hline
\end{tabular}

Table 3. WaterPoints provided by the donors intervention.

\begin{tabular}{ccccccccc}
\hline Type & Ikaram & Ibaram & Iyani & Erusu & Gedegede & Ase & Ajowa & Total \\
\hline Solar Powered Borehole & 4 & 0 & 1 & 2 & 0 & 0 & 4 & 11 \\
Submersible Pumped Borehole & 2 & 0 & 0 & 1 & 1 & 0 & 1 & 5 \\
Hand Pump Fitted Borehole & 7 & 0 & 1 & 3 & 1 & 1 & 6 & 19 \\
Rehabilitated Borehole & 0 & 0 & 0 & 0 & 0 & 0 & 0 & 0 \\
Protected Hand-Dug Well & 1 & 1 & 0 & 1 & 0 & 1 & 1 & 5 \\
Total & 14 & 1 & 2 & 7 & 2 & 2 & 12 & 40 \\
\hline
\end{tabular}

the key decision making in respect of site selection, neglecting the youth and vulnerable groups. In addition, there was strong indication that project implementer played a key role on site selection. Specifically, Figure 3 showed that $100 \%$ of the respondents at Gedegede and Ase identified the donor (the project implementer) as sole decision maker on site selection. In Ikaram, 54.8\% of the inhabitants affirmed that the donor was the key decision makers on site selection. However, $37.5 \%$ and $40 \%$ in Erusu and Ibaram submitted that the village elders were involved in site selection. Similar report was obtained in Ajowa where almost $60 \%$ of inhabitants identified the village elders as the key decision maker on site selection. In general, it could be concluded that the implementer in most of the villages decided on suitable site for project development. Interaction with Key Informants and information obtained during FGD indicate that donors assumed that the village elders were not suitably positioned to decide on appropriate sites for projects due to lack of required knowledge especially with respect to soil, climate and topography of the preferred area.

In the case of project identification, planning, design, implementation, monitoring and evaluation Table 4 showed that $37 \%$ of the inhabitants in Erusuvillage participated in the identification process of the project. In Ibaram, $25 \%$ of the community members were involved in the identification and planning process. Similar report was obtained in Iyani and Ikaram villages where $40 \%$ and $17.2 \%$ respectively claimed to have participated in monitoring and evaluation process. Whilst all the respondents (100\%) in Ase village participated in the design 


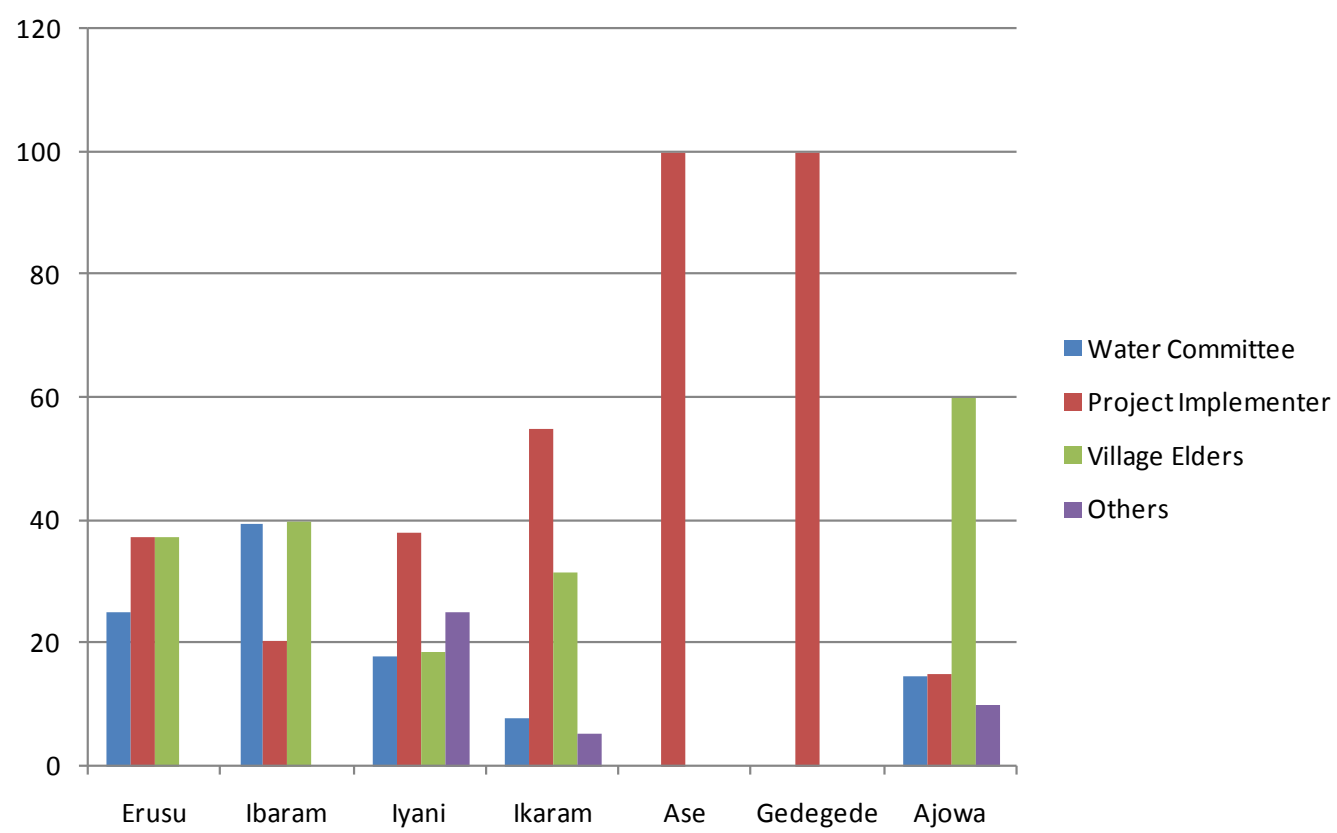

Figure 3. Decision making on site selection.

Table 4. Type of participation in the project.

\begin{tabular}{cccccc}
\hline & Identification & Planning & Design & Implementation & Monitoring and Evaluation \\
\hline Erusu & $37 . \%$ & $0 \%$ & $12.5 \%$ & $0 \%$ & $22.2 \%$ \\
Ibaram & $25 \%$ & $25 \%$ & $0 \%$ & $0 \%$ & $0 \%$ \\
Iyani & $0 \%$ & $0 \%$ & $20 \%$ & $40 \%$ & $40 \%$ \\
Ikaram & $10.3 \%$ & $10.3 \%$ & $0 \%$ & $20 \%$ & $17.2 \%$ \\
Ase & $0 \%$ & $0 \%$ & $100 \%$ & $0 \%$ & $0 \%$ \\
Gedegede & $25 \%$ & $0 \%$ & $50 \%$ & $0 \%$ & $25 \%$ \\
Ajowa & $16.3 . \%$ & $41.9 \%$ & $18.6 \%$ & $2.3 \%$ & $20.9 . \%$ \\
\hline
\end{tabular}

process and in Gedegede, $100 \%$ of the community members claimed to have participated in the design process. 41.9\% of the community members in Ajowa participated in the planning process. A critical examination of these results indicate that the planning and implementation of the water project were largely donor driven, a situation which does not engender project sustainability.

Community participation in which the community takes the responsibility of managing the water supply systems by themselves is one of the key indicators for sustainable community management in rural water supply schemes. Prior the intervention, the communities have demonstrated high level of responsibility in regard to the maintenance of the existing water points. For example, the communities have endeavoured to maintain both hand pumps fitted to boreholes and motorised boreholes to the extent that 21 out of 34 hand pumps fitted to boreholes are still functioning while 16 out of 28 motorised boreholes are still in good condition. It is evident that during the intervention 40 water points were provided by the donors in Ikaram MV (Table 5) and 72 toilets as shown in (Table 6) were provided which comprised ventilated improved pit latrine (33), sanitation platform latrine (39). All these water and sanitation points were being maintained by the community based committees and they are found to be in good condition. This implies that the technical training received by the members has served as catalyst for sustainable use of the water and sanitation facilities in the MV. It is gathered that two persons in each community have been trained to handle construction of water and sanitary facilities while another two have received training on the repair and maintenance of those facilities. The trained members of the community are saddled with the responsibility of retraining other interested members of the community. App- 
Table 5. No. and types of water points provided by MVP disaggregated according to communities.

\begin{tabular}{cccccccc}
\hline Type & Ikaram & Ibaram & Iyani & Erusu & Gedegede & Ase & Ajowa \\
\hline Solar Powered Borehole & 4 & 0 & 1 & 2 & 0 & 0 & 4 \\
Submersible Pumped Borehole & 2 & 0 & 0 & 1 & 1 & 0 & 1 \\
Hand Pump Fitted Borehole & 7 & 0 & 1 & 3 & 1 & 1 & 6 \\
Rehabilitated Borehole & 0 & 0 & 0 & 0 & 0 & 0 & 0 \\
Protected Hand-Dug Well & 1 & 1 & 0 & 1 & 0 & 1 & 2 \\
Total & 14 & 1 & 2 & 7 & 2 & 2 \\
\hline
\end{tabular}

Table 6. No. and types of toilet facilities constructed by MVP in each community.

\begin{tabular}{|cccccccc}
\hline Type & Ikaram & Ibaram & Iyani & Erusu & Gedegede & Ase & Ajowa \\
\hline Ventilated Improved Pit (VIP) Latrine & 10 & 1 & 2 & 6 & 3 & 2 & 9 \\
Sanitation Platform (SANPLAT) Latrine & 5 & 5 & 5 & 8 & 6 & 5 & 5 \\
Total & 15 & 6 & 7 & 14 & 9 & 7 & 14 \\
\hline
\end{tabular}

arently, $40.4 \%$ of the community members claimed to have repaired water facilities that suffered breakdown in the villages by employing local technicians that were trained on the maintenance of the water facilities by the project while others engaged the services of hired technicians (28.3\%), Local Government technicians (8.1\%) and artisans provided by NGOs (16.2\%) and CBOs (7.1\%) (Table 7). In addition, it was observed that $43 \%$ of the respondents affirmed that the Water Committee paid for the repair work. However, 5\% asserted that it was the Local Government that financed water repair works, 25\% believed that individual philanthropistswere solely responsible for financing repairs. In general, the result indicates that repair works were usually handled by the Water Committeewhile fund for the payment of the repair services was obtained from the pool of money contributed by the community members. Table 8 showed that $40.2 \%$ of the respondents had indicated willingness to contribute between $¥ 0$ - $¥ 500$ for maintenance of the various water facilities provided by the millennium village project, 24.1\% were ready to contribute $\$ 501$ - $\$ 1000,8.0 \%$ signified readiness to pay between $¥ 1001$ -

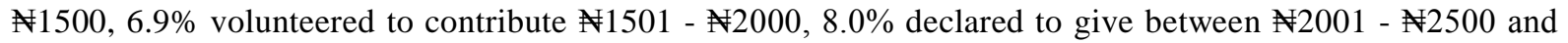
$12.6 \%$ were willing to contribute more than $\$ 3000$. Generally in all the communities, a larger percentage of the population were willing to contribute less than 1000 for the maintenance of the various water facilities. This could, in a way, facilitate the proper repair and maintenance of the facilities there by encouraging the sustainable use of the facilities.

During FGD and KII, it was concluded by the community members that the project management structure appears too complex for a typical integrated village development project. They opined that decisions ought to have been taken at the level of the community and the closest administrative levels (local and state governments) rather than from Abuja-Bamako and New York. Again, it was revealed that irrespective of the participatory approach adopted by the implementer of the project in the preparation of the work plans and budgets including prioritized activities, UNDP still reviewed, amended and finally approved such plan. Thus, such process can in no way be considered to be community-led, empowered or strongly participatory since the final plan is at the instance of the donor. A fundamental principle of any participatory development process is to remove and or reduce the hierarchy of decision-taking by creating a means whereby power and knowledge are more equally shared. A participatory development approach therefore seeks to build understanding between two different strands of knowledge: local knowledge of which villagers are more knowledgeable and scientific knowledge of which outsiders are more well-informed. However, in the MV, the science component is currently structured as an extractive process whereby science experts and MVP staff are designing and processing research data and conducting studies of which the community has little or no understanding. In this regard, the MVP villagers are not benefiting from knowledge that would have assisted in the scaling-up and sustainability being envisaged by MVP model.

The local government officials that were interviewed during KII expressed their willingness to participate in the planning and implementation of the MV project. However, they concluded that the MVP officials not adopt 
Table 7. Maintenance of water project.

\begin{tabular}{cc}
\hline Category & Percent \\
\hline Local technician trained on maintenance & 40.4 \\
Hired technician & 28.3 \\
Local govt technician & 8.1 \\
NGOs & 16.2 \\
CBOs & 7.1 \\
Total & 100.0 \\
\hline
\end{tabular}

Source: Author’s Fieldwork, 2015.

Table 8. Residents’willingness to contribute for the maintenance in ( $)$.

\begin{tabular}{|c|c|c|c|c|c|}
\hline & & Frequency & Percent & Valid Percent & Cumulative Percent \\
\hline \multirow{8}{*}{ Valid } & $\cong 0-\mathrm{N} 500$ & 28 & 28.3 & 36.8 & 36.8 \\
\hline & N501 - 1000 & 8 & 8.1 & 10.5 & 47.4 \\
\hline & \$1001 - 1500 & 15 & 15.2 & 19.7 & 67.1 \\
\hline & $\$ 1501$ - 2000 & 5 & 5.1 & 6.6 & 73.7 \\
\hline & N2001 - 22500 & 3 & 3.0 & 3.9 & 77.6 \\
\hline & N2501 - 3000 & 4 & 4.0 & 5.3 & 82.9 \\
\hline & More than $\$ 3000$ & 13 & 13.1 & 17.1 & 100.0 \\
\hline & Total & 76 & 76.8 & 100.0 & \\
\hline
\end{tabular}

a coordinated approach to planning, budgeting and reporting at ward and local government level. Paradoxically, sustainable development could only be achieved by actively involving the community and local government in the related activities [28] [29].

It was further observed during the FGD, that the different types of existing community institutions such as community based organizations (CBOs), informal credit groups, cooperative groups, youth groups, faith-based groups, sports clubs, farmers groups, traders associations and other types of groups which can be useful in projectplanning, design, implementation and management were not fully consulted. In addition, the role of existing community power structures such as traditional leaders in the MV was not integrated into the community development process as they were not fully consulted in the planning and implementation of the MV project. The need to work in harmony with existing institutions is not only pertinent but aids in capacity building and project sustainability.

\subsection{Cost Sharing}

Element of community contributions to capital and recurrent costs of running and maintaining the system is critical to sustainability. Such contribution might not necessarily be financial in nature. It has been contended that the more a community contributes to and benefits from projects, the more sustainable the community development [30]. The costs of the MVP package are estimated at about US\$120 per person per year, for a five year period. These are expected to be co-funded by grants from governmental and non-governmental donors, national and local governments and community-based contributions. The breakdown of the cost per person indicates donor funds \$60; local and national governments funds $\$ 30$; partner organizations funds $\$ 20$ and village members funds (time and expertise) \$10. Base on the fact that the village clusters represent high incidences of rural poverty and hunger, the members result into the use of selp-help approach to contribute to the implementation of the MVP. The community members were not able to meet their full financial responsibility towards the project development. The study established that due to low economic base of the MV, low financial and local materials were contributed towards the water project development. Given this weak economic situation 
of the community members, it may be difficult to provide and meet the financial requirement for sustaining the water project without any serious intervention from the Federal, State and Local Governments.

Figure 4 indicates that all respondents in Ase, Erusu and Ibaram recognized provision of communal land as the most dominant type of community members' participation in water projects while in Iyani, Ikaram and Ajowa $60 \%, 80.6 \%$, and $72.1 \%$ respectively share the same view. Also the Figure revealed that there were low financial and material contributions to water project among all the communities. However, $100 \%$ of the respondents in Gedegede, $40 \%$ in Iyani and less than $10 \%$ in Ajowa claimed to have provided free labour during the construction phase of the project. With low financial and local materials contributions, it implies that the economic base of the community members tend to weaken the levelof community participation in the water project and its subsequent sustainability.

\subsection{Ownership and Control}

To ensure sustainability, the community must own their water infrastructure. Even though this may not always be fully possible, there must be perception of ownership by the user community. The consistency of training and education of community members is expected to greatly contribute to ownership of water projects. Most community members believed that the content of the training session was moderately adequate and also sensitize them on how best to manage their water infrastructure. It was evident that the community members had received training on repair of waterworks andfitting of street stand pipe. Suchcapacity building efforts provide the needed skills for immediate rectification among community members in case of any system breakdown. This is expected to keep the project functional for meeting the need of the community even after the disengagement of the donor. However, the poor economic base of the clusters had discouraged some community members from attending the training on the basis of the fact that they were not ready to compromise the time for their occupation thereby missing the process of skill acquisition that suppossed to confer on them a level of control over the operation and maintenance of the water project.

Table 9 showed that all respondents in Asebelieved that the education and training given to the community members on water project have developed community awareness on water supply problems. This perception has strong tendency to increase local participation in water project thereby enhancing their ownership of such project. Similar opinion was expressed by $80 \%$ of respondents in Iyani, $75 \%$ in Gedegede, $50 \%$ in Ibaram and $62.5 \%$ in Erusu. Essentially, $44.2 \%$ of the respondents received training on repair of water facilities while $9.5 \%$ received training on fitting of street stand pipes.

Table 10 showed that $13.1 \%$ expressed a belief thatthe consistency of the training and education in the MV has greatly contributed to ownership of water projects. Another $24.2 \%$ felt that it contributed to ownership of water project just a little below average, $48.5 \%$ believed it contributed to ownership of water projects just averagely, $8.1 \%$ felt it just contributed to ownership of water projects minimally while $6.1 \%$ believed it has not

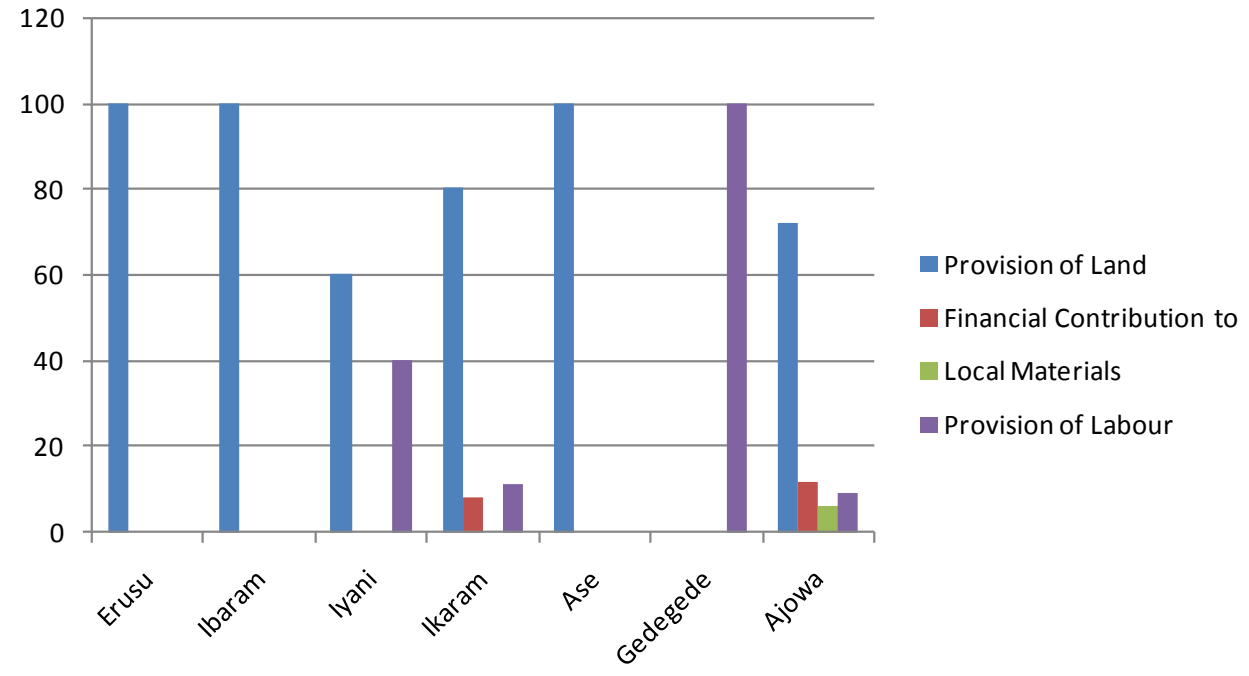

Figure 4. Nature of community members cost sharing. 
Table 9. Education and training given on water project and awareness creation.

\begin{tabular}{cccc}
\hline & Yes & No & Don't Know \\
\hline Erusu & $62.5 \%$ & $12.5 \%$ & $25 \%$ \\
Ibaram & $60 \%$ & $20 \%$ & $20 \%$ \\
Iyani & $80 \%$ & $0 \%$ & $20 \%$ \\
Ikaram & $50 \%$ & $34.4 \%$ & $15.6 \%$ \\
Ase & $100 \%$ & $0 \%$ & $0 \%$ \\
Gedegede & $75 \%$ & $0 \%$ & $25 \%$ \\
Ajowa & $58.1 \%$ & $25.6 \%$ & $16.3 \%$ \\
\hline
\end{tabular}

Source: Author’s Fieldwork, 2015.

Table 10. Consistency of education and training.

\begin{tabular}{cc}
\hline Parameters & Percent \\
\hline very great extent & 13.1 \\
great extent & 24.2 \\
moderate extent & 48.5 \\
little extent & 8.1 \\
not at all & 6.1 \\
Total & 100.0 \\
\hline
\end{tabular}

contributed to ownership of water projects at all. These results suggest that the series of training were beneficial to ownership of water projects.

In addition, most community members (85.8\%) believed that the content of the training was adequate and has sensitized them on how best to manage their water infrastructure (Table 11). This indicates that the content of the trainingwas sufficient to provide the community members the prerequisite knowledge required for the management of water infrastructure.

\subsection{Challenges to Sustainability of Water Projects in MV}

Poor government attitude towards continuity was found to be the major challenge (35\%) of sustainability of water project in the MV (Table 12). Following programme closure by the donor, the government was to support the sustainability of this project. However, the Ondo State Multilateral Office confirmed that such support did not come. This greatly hampered facility maintenance and community mobilization for further support for this programme. It was further observed that community attitude to project maintenance in these communities was rather too poor. This is amplified by their weak financial capability. This coupled with poor community leadership (8\%) and poor community mobilization (7\%) hampered the ability of the various water users association to be able to mobilize enough resources to promote sustainability. The community also reported pockets of facility breakdown arising from vandalism (11\%). Such vandalismwas mostly carried out by youths and touts. The villagers also note that donor's attitude did not foster sustainability (19\%) as water projects were largely ignored after construction without checking back whether the projects were being run in a sustainable manner.

\section{Conclusion}

The sustainability of the MVP water project based on its current operation in the village clusters tend to be inhibited by poor economic base of the clusters both on the part of the community and closest local governmnet that had to contend with other communities' needs. Also, the MVP's limited emphasis on the preparation and execution of a coordinated approach to planning, budgeting and reporting at ward and local government level constraint the sustainability of the water project. Sustainable development is achieved by actively involving the 
Table 11. Content of the education and training.

\begin{tabular}{cc}
\hline Parameters & Percent \\
\hline Very great extent & 9.1 \\
Great extent & 25.3 \\
Moderate extent & 38.4 \\
Little extent & 18.2 \\
Not at all & 8.1 \\
Nill & 1.0 \\
Total & 100.0 \\
\hline
\end{tabular}

Table 12. Challenges to sustainability of donor-support water projects in the MV.

\begin{tabular}{|c|c|c|}
\hline Challenge & Frequency & Percentage (163) \\
\hline Poor government attitude towards continuity & 57 & 35 \\
\hline Poor community attitude to project maintenance & 42 & 26 \\
\hline Vandalism & 18 & 11 \\
\hline Poor community leadership & 8 & 5 \\
\hline Poor community mobilization & 7 & 4 \\
\hline Donor attitude to sustainability & 31 & 19 \\
\hline
\end{tabular}

community and local government in the related activities [28] [29]. The poor economic base of the clusters had discouraged some community members from attending the training on the basis of the fact that they were not ready to compromise the time for their main economic activity thereby missing the process of skill acquisition that suppossed to confer on them a level of control over the operation and maintenance of the water project. Based on the fact that the village clusters represent high incidences of rural poverty and hunger, the members result into the use of selp-help approach to contribute to the implementation of the MVP. This implies that their financial incapability will to a large extent affect the maintenance of the water source points and by extension inhibits the sustainability of the water and sanitation projects.

\section{References}

[1] World Bank (2003) Water and Sanitation Programme, Focus Areas: Rural and Small Towns Water Supply and Sanitation. http://www.worldbank.org/watsan/rwsstoolkit/index.htm

World Bank. Scaling-Up the Impact of Good Practices in Rural Development: A Working Paper to Support Implementation of the World Bank’s Rural Development Strategy. Report Number 26031.

[2] Federal Ministry of Water Resources (2004) Draft National Water Supply and Sanitation Programme a Strategic Framework.

[3] WHO and UNICEF (2012) Progress on Sanitation and Drinking Water-2012 Update. WHO and UNICEF Joint Monitoring Programme, WHO Press, Geneva.

[4] WHO \& UNICEF (2014) Progress on Sanitation and Drinking Water Update. WHO Press, Geneva.

[5] Yahaya, S. (2004) Meeting the Targets for Water Supply and Sanitation: The African Challenge, Operation Policy and Review Department, ADB, 323.

[6] UNDP (2004) Sustainable Development Networking Programme, Report of an Independent External Assessment. http://www.Sdnp.Undp.org/SDNPassessment-report-final.pdf

[7] UNDP (2006) The Millennium Development Goals Report: 2006. www.undp.org/publications/MDGReport2006.pdf

[8] Millennium Village Project (2008) The Millennium Village Project Annual Report. Earth Institute Columbia University, New York.

[9] Sachs, J.D. and McAuthur, W.J. (2009) Update/d Concept Note on the Millennium Villages Project: Scalability, Sustainability, and Early Lessons. john.mcarthur@millenniumpromise.org 
[10] Laryea, O.N. (1994) Challenges and Prospects of Community Management in Ghana UNPD/GWSC Rural Water and Sanitation Project. WEDC Publication, Sri Lanka.

[11] Eguavoen, I. (2006) Drinking Water Policy. Water Rights and Allocation Practice in Rural Northern Ghana. Bonn.

[12] Roark, P., Hodgkin, J. and Wyatt, A. (1993) Models of Management Systems for the Operation and Maintenance of Rural Water Supply and Sanitation Facilities. World Health Organization.

[13] Chovwen, A., Orebiyi, O., Savadogo, A.S., Afere, T. and Afolayan, A. (2009) Achieving the Millennium Development Goals: An Assessment of Water and Sanitation Intervention of the Ikaram Millennium Village, Nigeria. Researcher, 1, 6-13.

[14] Mark, S.J. and Davis, J. (2012) Does User Participation Lead to Sense of Ownership for Rural Water Systems? Evidence from Kenya. World Development, 40, 1569-1576. http://dx.doi.org/10.1016/j.worlddev.2012.03.011

[15] Ihuah, P.W. and Kakulu, I.I. (2014) Rural Water Supply Projects and Sustainable Development in Nigeria. Journal of Sustainable Development in Africa, 16, 56-68.

[16] Lockwood, H. (2004) Scaling up Community Management of Rural Water Supply: Thematic Overview. IRC International Water and Sanitation Centre, Delft.

[17] Abrams, C. (1998) Understanding Sustainability of Local Water Services. http://www.africanwater.org/sustainability.html

[18] Parry-Jones, S., Reed, R. and Skinner, B.H. (2001) Sustainable Hand Pump Projects in Africa: A Literature Review. WEDC, Loughborough University, Loughborough.

[19] Baumann, E., Ball, P. and Beyene, A. (2005) Rationalization of Drilling Operations in Tanzania: Review of the Borehole Drilling in Tanzania. RWSN, Dar Es Salam.

[20] WELL (1998) DFID Guidance Manual on Water Supply and Sanitation Programs. London, UK.

[21] Ngetich, R.C. (2009) Assessment of Factors Influencing Projects Sustainability, the Case of Community Water Projects in Keekonyokie Central Location of Kajiado North District, Kenya. Unpublished Thesis of University of Nairobi, Nairobi.

[22] Habtamu Addis, B. (2012) Factors Affecting the Sustainability of Rural Water Supply Systems. The Case of Mecha Woreda Amhara Region, Ethiopia. Unpublished Thesis of Cornell University, Ithaca.

[23] Rimbera, P.K. (2012) Determinants of Water Projects Sustainability: A Case of Water Projects in Kieni East Division, Nyeri County Kenya. Unpublished Thesis of University of Nairobi, Nairobi.

[24] AliJatan, B. (2012) Determinants of Community Ownership of Water Projects in Kenya. A Case of Central Division, Isiolo County. Unpublished Thesis of the University of Nairobi, Nairobi.

[25] Olajuyigbe, A.E. and Fasakin, J.O. (2010) Citizens' Willingness to Pay for Improved Sustainable Water Supply in a Medium Sized City in South Western Nigeria. Current Research Journal of Social Science, 2, 41-50.

[26] Idris, T. (2012) Housing Conversion in Mushin Local Government. An Unpublished Project Submitted to Department of Design and Architecture (Urban and Regional Programme) Olabisi Onabanjo University, Ago-Iwoye.

[27] Millennium Village Project (2007) The Millennium Village Project Annual Report. Earth Institute Columbia University, New York.

[28] UNMP (2014) Millennium Villages: A New Approach to Fighting Poverty. http://www.unmillenniumproject.org/mv/mv_closer.htm

[29] Alimba, N.C. (2007) Community Participation in the Management of the Education System. African Journal of Historical Sciences in Education, 3, 97-110.

[30] Asiabaka, C.C. (2008) Beneficiary Impact Assessment of Parasitic Weed Pilot Sites in Cereal Legume Systems: Northern Guinea Savannah, Nigeria. International Institute of Tropical Agriculture, SP-IPM, Ibadan, Nigeria. 